\title{
The Role of the Societas Meteorologica Palatina (1781-1792) in the History of Auroral Research *
}

\author{
Per Pippin Aspaas ${ }^{1}$ \& Truls Lynne Hansen ${ }^{2}$
}

\author{
${ }^{1}$ University Library of Troms $\varnothing$, University of Troms $\varnothing, \mathrm{N}-9037$ Troms $\varnothing$, Norway \\ per.pippin.aspaas@uit.no \\ ${ }^{2}$ Troms $\varnothing$ Geophysical Observatory, University of Troms $\varnothing$, N-9037 Troms $\varnothing$, Norway \\ truls.hansen@uit.no
}

\section{ABSTRACT}

The Societas Meteorologica Palatina, or Meteorological Society of Mannheim, was set up in 1781 to coordinate observations of the weather on an international scale. In addition to temperature, pressure and humidity, observers connected to the network were instructed to record various atmospheric phenomena, among these the aurora borealis. The thirty-nine stations of the network reported about 1400 individual sightings of auroras during the Society's dozen years of existence.

The reported sightings are subjected to a statistical analysis that brings out striking discrepancies between the number of auroras that one would expect and the number that was reported. The statistical analysis is supplemented by an analysis of the theoretical and phenomenological comments in the Society's annual reports.

The study suggests that observers on the Continent considered themselves just as advantageously situated as observers further north when trying to solve the riddle of the northern lights. It also illustrates the variety of conflicting ideas about the aurora borealis that existed during the late Enlightenment, and how these might have influenced the number of reported auroras. This lack of consensus contributed to many anomalies in the data presented in the Society's reports. By combining linguistic and scientific competence it is possible to shed light on these anomalies and on the historical context that shaped them.

\section{KEYWORDS}

Aurora Borealis, Meteorology, History of Science, $18^{\text {th }}$ Century, Scientific Societies, Mannheim

\footnotetext{
${ }^{*}$ This is the final manuscript version (after referee process and copy editing) as submitted to the journal Acta Borealia: A Nordic Journal of Circumpolar Societies in October 2012. It formed part of a special issue on The History of Research into the Aurora Borealis (Vol. 29, Issue 2, guest editors Per Pippin Aspaas, Robert Marc Friedman and Sven Widmalm). The publisher Taylor and Francis does not allow us to make the published PDF available Open Access without paying a heavy fee. The published PDF's full reference is Acta Borealia Vol. 29, Issue 2 (2012), pp. 157-176 = DOI:10.1080/08003831.2012.732283. - The authors.
} 


\section{The Role of the Societas Meteorologica Palatina (1781-1792)}

\section{in the History of Auroral Research}

The Meteorological Society of Mannheim, or Societas Meteorologica Palatina, is primarily remembered for having established an international network of meteorological stations that measured temperature, pressure, humidity etc., three times a day. Identical instruments were produced in Mannheim and distributed to each station along with detailed instructions to ensure compatible sets of data. The "Mannheim times" for measurement, 7 am, 2 pm, and 9 pm are still standard; the Society's annual reports, the Ephemerides Meteorologicae Societatis Palatinae covering the years 1781-1792 continue to be consulted by historians of meteorology and climate change (e.g. Kistner, 1930: 95-109; Anon. [ed], 1980; Kington, 1988; Schröder \& Colacino [eds], 1994; Lüdecke [ed], 2006).

The Meteorological Society was active in other fields as well. The observers connected to the network were not only expected to record objective data provided by the thermometer, the barometer, and the hygrometer, they were also asked to report in a separate section sightings of socalled "Meteora". These observations entailed a more subjective scrutiny of the skies for which an individual's skills and understanding could play a decisive role. One of the "meteors" that was of particular interest to the organizers of the network was the enigmatic aurora borealis. Altogether thirty-nine international stations were involved for shorter or longer periods during the Society's dozen years of operation; about 1400 aurorae are recorded in its annual reports. Although this rich material was used by Hermann Fritz in his comprehensive work on the statistics of the aurora borealis (Fritz, 1873; Fritz, 1881), it appears to have been overlooked in recent surveys of the history of research into the phenomenon (e.g. Brekke \& Egeland, [1979] 1994; Eather, 1980; Schröder, [1984] 2000; Sandahl, 1998; Stauning, 2011). 
Per Pippin Aspaas \& Truls Lynne Hansen, “The Role of the Societas Meteorologica Palatina (1781-1792)..." final MS version

This article highlights the role played by the Meteorological Society in auroral research. True, the coordinators in Mannheim showed an marked interest in the aurora. But the network, while international, nonetheless had its highest density of participating stations on the European

Continent. The Mannheim organizers were not particularly eager to establish meteorological stations in the Far North. As regards the aurora borealis, this phenomenon was not perceived by the leading members of the Meteorological Society to be a particularly northern phenomenon.

Several observers on the Continent seem to have considered themselves to be as favourably placed as anywhere else for investigating the aurora. The findings presented here thus offer a comment on the belief, so frequently put forward by Nordic investigators since the early eighteenth century, that the riddle of the northern lights was bound to be solved in the North. This belief was not necessarily shared further south, as the history of the Meteorological Society's engagement with the aurora illustrates.

A principal aim of our study is to provide examples of how early-modern observers struggled to come to terms with various fleeting optical phenomena and to determine what was an aurora borealis and what was not. We will employ the annual reports of the Meteorological Society for a case study of this problem. The number of sightings of aurora reported by the stations sometimes vastly exceeded that which can be expected based on the present scientific understanding of solarterrestrial phenomena. Moreover, much greater variation in the number of aurora reported from station to station in relatively close proximity also seems puzzling in light of present knowledge. In addition to these statistical anomolies, descriptions of individual sightings and theoretical reflection put forward by members of the network strongly suggest that the international scholarly community had yet to achieve a consensual understanding of the aurora as a visual phenomenon. Just what observers were allegedly looking for and reporting under the rubric of "aurora borealis" was itself a problem. 
Per Pippin Aspaas \& Truls Lynne Hansen, “The Role of the Societas Meteorologica Palatina (1781-1792)..." final MS version

This raises a further problem. Historical records of auroral activity figure in on-going discussions of the influence of the Sun on the climate. Climate-change researchers use statistical overviews of auroral outbreaks per year, along with other parameters such as sunspot observations, as data for their models. This use of historical auroral data is highly precarious. Given the lack of consensual agreement to the very notion of the aurora borealis and given that change over time of what was being recorded as an occurrence of aurora, the reliability of such data sets for reconstructing climate change is questionable. By bringing scientific, linguistic, and historical insight to the task, this study seeks to identify spurious reports of aurora in the data and to propose possible sources of what today would be termed as "error".

\section{The Societas Meteorologica Palatina and early modern meteorology}

Meteorology was an important field of research in the Age of Enlightenment. The ideology of the time among the learned promoted empirically based, "rational" science to explain natural phenomena rather than the traditional lore and superstition of the common people. Documentation of the weather from year to year, combined with medical records of diseases and birth-and mortality rates, was seen as a means to enhance public health. Astrological beliefs regarding sowing and harvesting were to be replaced by a scientific investigation of the weather that in due course was to lead to improved methods of agriculture. Similarly, popular interpretation of northern lights and other spectacular phenomena in the sky as omens was to be refuted by means of reason. The Meteorological Society was not alien to such rhetoric (e.g. Cassidy, 1985), but its raison d'être was broader than simply the quest for utility and rationality.

Meteorology in the early modern period was pursued by researchers from three fields; medicine, experimental physics and astronomy. From early on, investigators of the weather felt the need to gather calibrated observations from different places in order to grasp the dynamics of the weather on a broader scale, not unlike the common practice of sharing and exchanging corresponding observations so characteristic of eighteenth-century astronomy (cf. Widmalm, 1992). 
Per Pippin Aspaas \& Truls Lynne Hansen, “The Role of the Societas Meteorologica Palatina (1781-1792)..." final MS version

Unlike in astronomy, however, where mutual exchange of compatible set of data quickly became routine, the internationalization and standardization of meteorology arose more slowly.

An early effort to harmonize meteorological observations was made by the Accademia del Cimento that flourished in the 1650 s and 60s under the patronage of Grand Duke Ferdinand II and his brother Prince Leopold of Tuscany. That network lasted for about ten years and foreshadows the Meteorological Society of Mannheim in certain respects. Observers connected to the Accademia del Cimento were equipped with identical instruments; they were asked to record the weather at fixed times at stations established over a deliberately broad geographic area. Although some stations were outside of Italy, the network remained primarily a local affair within Tuscany. The effect of the Accademia was greater however than the mere distribution of its observers. The thermometer was spread across Europe, and the very notion of standardized meteorological observations took hold amongst proponents of science. Similar, albeit more local, initiatives were taken in London and Paris around the middle of the seventeenth century. Later efforts were often broader in scope, but lacked the successes characterizing the Societas Meteorologica Palatina in terms of standardization. As an example, in 1723 the secretary of the Royal Society of London issued a letter of invitation to submit meteorological observations. Reports arrived from localities around the globe for a period of about ten years, but no effort was made to use calibrated instruments. In the 1770 s, interest in meteorology peaked. Influential natural philosophers in several countries published meteorological treatises. The need for coordinated observations in order to answer several questions relating to what we would now call "climatology" was strongly felt. The obvious utility of meteorology for agriculture and navigation received further impetus from basic questions regarding the distribution and properties of plants, diseases, electricity, magnetism - and even morals, as in the famous example of Montesquieu (Feldman, 1990; Colacino \& Valensise, 1994; Frängsmyr, 2000).

Most relevant of the numerous projects to study weather and climate was an initiative taken by the professor of physics Johann Lorenz Böckmann (1741-1802) in Karlsruhe, which influenced the 
Per Pippin Aspaas \& Truls Lynne Hansen, “The Role of the Societas Meteorologica Palatina (1781-1792)..." final MS version

founding of the Meteorological Society of Mannheim. In the year 1778, Böckmann succeeded in setting up a network comprising sixteen meteorological stations within the Margravate of Baden. He planned to expand the network beyond that single German state, but after merely a year lack of funds forced further initiatives to be aborted. Böckmann's network disintegrated; he withdrew from meteorological research (Cassidy, 1985: 17-18; Lüdecke, 2002; Moutchnik, 2006: 326-327).

Böckmann's activities were followed closely in the German-speaking areas of Europe. In Mannheim, a group was ready to take over as soon as his efforts had stalled. The Societas Meteorologica Palatina, or Meteorological Society of the Palatinate (Kurpfalz), was formally established in September 1780. The scientific initiators of the enterprise were the court priest and head of the Naturalienkabinett Johann Jakob Hemmer (1733-1790), the director of the Mannheim Academy of Sciences Georg von Stengel (1722-1798), and the court astronomer and experimental physicist Christian Mayer (1719-1783). They received lavish funding from their patron, Prince Charles Theodore. As Elector (Kurfürst) of the Palatinate and Bavaria (Bayern), he was a prince widely known as a supporter of the sciences and the arts. One of the first steps of Hemmer, Stengel, and Mayer was to recruit to Mannheim Böckmann's former instrument maker. They also established a printing press to enable them to publish the annual reports in the costly quarto format. With funding secured and an institutional framework in place, the founding fathers then started inviting participants into their network of meteorological stations.

From the very outset Hemmer, Stengel, and Mayer aimed to establish an international network. Apart from places within the Elector's area of administration, letters of invitation were sent to institutions of learning distributed over a wide geographical area ranging from Stockholm to Rome and from Saint Petersburg to Lisbon (further expansions into Siberia and North America came later). In addition to letters sent by the scientific organizers, diplomatic channels were used to solicit participants. Some declined, but in the end a total of thirty-nine stations were included in the network for shorter or longer periods over the Society's dozen years of existence. Not surprisingly, 
central and southern Germany were heavily represented, whereas the predominantly Protestant northern Germany had no stations at all. Still, it seems that the Society nevertheless embraced the cosmopolitan ideals of the early-modern Republic of Letters in that non-Catholic states were included: Orthodox Russia, Anglican Britain and Lutheran Denmark and Sweden were represented in the first round of invitations (Eph.Met. Anni 1781 [1783]: 23-40). As the studies of amongst others Adina Ruiu (2007) and Päivi Maria Pihlaja (2009; 2012) have demonstrated, the High North had become an area of special interest for many savants in their search for new scientific knowledge during the early modern period. In his quest to determine the shape of the Earth, Maupertuis had opted for the Tornedalen Valley in far-northern Sweden for his expedition of the 1730s. The exotic flavour of the Flora Lapponica contributed to bestow world-wide fame to Carl Linnaeus and ultimately - to his binomial system of nomenclature. And in the international effort to determine the size of the solar system by means of coordinated observation of the transits of Venus of 1761 and 1769, data sets from the northernmost parts of Europe were particularly cherished (Aspaas, 2012). As far as the aurora borealis is concerned, a special interest in observations from far-northern parts of Europe can be noted throughout the eighteenth century. Investigators in the Nordic countries argued patriotically that they possessed advantages over their peers on the Continent because of their "proximity" to the aurora. This idea was not necessarily shared by scholars in the south. It is telling that Jean-Jacques d'Ortous de Mairan in Paris - famous for his Traité Physique et Historique de l'Aurore Boreale (1733; $2^{\text {nd }}$ edn. 1754) - acknowledged that the frequency of auroral outbreaks was probably greater in the North. De Mairan was not, however, convinced that Nordic observers were diligent and exact enough to provide reliable observations, nor - by implication - able to present a reliable explanation of the phenomena (Mairan, 1733: 76; Aspaas, 2013).

For all this contemporary interest in northern issues, the Meteorological Society of Mannheim appears not to have been particularly interested in the Far North as a priviledged site for knowledge of nature. When the founding fathers started to invite institutions to participate in the network, the northernmost places they turned to were Edinburgh, Copenhagen, Stockholm and Saint 
Per Pippin Aspaas \& Truls Lynne Hansen, “The Role of the Societas Meteorologica Palatina (1781-1792)..." final MS version

Petersburg. When eventually one station in Norway (Spydeberg) and another in Greenland

(Godthaab) were included, this arose through the initiative of the Astronomer Royal in Copenhagen,

Thomas Bugge (1740-1815). It was an expansion that was welcomed, but hardly instigated by the founding fathers in Mannheim (Eph.Met. Anni 1787 [1789]: VI-VII; cf. Federhofer, 2001; Lüdecke, 2005). Arguably, if the Meteorological Society of Mannheim had been eager to study northern nature, it should have sought to include at least the Royal Society of Sciences in Trondheim. Established in 1760 and granted Royal epithet in 1767, the Trondheim Society was eager to gain international recognition (Andersen et al., 2009). The first volumes of its proceedings were translated into German; they included extensive weather reports from Trondheim and other places in Norway (Der Drontheimischen Gesellschaft Schriften 1-3; Der Königl. Norwegischen Gesellschaft der Wissenschaften Schriften 4). Scientific staff at the university in Åbo (Turku) or the talented member of the Royal Swedish Academy of Sciences in far-northern Torneå (Tornio), Anders Hellant (17171789), would also have been possible candidates from high latitudes (cf. e.g. Lindroth, 1978; Lindroth \& Eriksson, 1981). However, there appears to have been no contact between Mannheim and persons or institutions outside the Nordic capitals.

The inclusion of Norway and Greenland in the network was thus an unintended side-effect of the network as it spun out from Mannheim. Moreover, the Society's relatively extensive research into the aurora may be characterised as a comparatively modest topic within its broader ambitious research programme. Nevertheless, the annual Ephemerides Meteorologicae constitute an important source on how early-modern observers on the Continent interpreted a quintessentially northern phenomenon.

The Societas Meteorologica formally existed for fifteen years. In the later years, however, it showed clear signs of disintegration. The founding fathers Mayer and Hemmer died in 1783 and 1790 respectively. Wars and upheavals resulted in financial constraints and impeded regular recordings in 
Per Pippin Aspaas \& Truls Lynne Hansen, “The Role of the Societas Meteorologica Palatina (1781-1792)..." final MS version

many places. The volumes became slimmer and the number of stations decreased. The report for the year 1792, published in 1795, marks the end of this notable scientific enterprise.

\section{Northern Lights in the north and south}

Fig. 1 shows the geographical distribution of the European stations connected to the Meteorological Society. In Europe's northernmost parts the aurora borealis is a common phenomenon in the night sky; observers would naturally be familiar with its appearance. The highest frequency of auroras are found in a belt crossing northernmost Fennoscandinavia, Iceland, and Greenland, the so-called auroral zone. As mentioned, a single station of the Societas Meteorologica was established within this zone, at Godthaab (Nuuk) in Greenland. Unfortunately, however, data from this station were included only in a single issue of the ephemeris and covered no more than a nine-month period (Eph.Met. Anni 1787 [1789]: 42-69; cf. Lüdecke, 2005 and Enebakk, 2012). In southern Scandinavia, where the northernmost long-term stations of the Mannheim network were found, the aurora was surely as well known to the observers as any other feature of the sky they were asked to record. Moving south to Germany it is seen only sporadically, and in periods of solar activity minimum it might be absent for years. South of the Alps the aurora is so rare that local observers would have a chance to see it only a few times in their lives. Presumably, very few of them had observing experience from northern Europe.

Not only did the rarity of auroras pose a challenge, so too did the puzzling and seemingly contradictory general properties of the aurora. While green is the dominant colour for a northern observer, deep red is most common when the aurora appears further south. In the north, a variety of structural forms is common - arcs, draperies, and corona - but the red aurora is normally more diffuse in structure. This red hue may be confused with other cases of red colours in the sky. It is no coincidence that the name aurora borealis ("northern dawn") was coined in the south (Siscoe, 1978; Aspaas, 2013). 
We have searched the Meteora column in all volumes of the Ephemerides Meteorologicae Societatis Palatinae for notes of "AB", the standard abbreviation for aurora borealis. In order to make the material more uniform we concentrated on the observing sites in western and central Europe, including Scandinavia but leaving out Russia, North America and Greenland. We have also excluded the year 1792 , because only a few stations were left by then and most of the data were presented only as summaries without entries for specific days. Only an insignificant number of ABs are left out by these restrictions. This leaves us with 1323 observations at twenty-nine sites, recorded between 1 January 1781 and 31 December 1791. The distribution is shown in Table 1. The Norwegian sites Spydeberg and Eidsberg are treated as a single station. They are close together and there is no overlap in time. For identical reasons the same procedure is applied to Delft and the Hague.

In the table the stations are listed in descending geomagnetic latitude, i.e. in increasing distance from Earth's Geomagnetic North Pole. This pole has a geomagnetic latitude of 90 degrees and is the centre of the auroral zone extending to around 67 degrees geomagnetic latitude. South of the auroral zone the number of observed auroras are expected to decrease with decreasing geomagnetic latitude; high frequency in Scandinavia and very few for the Mediterranean sites. The last column holds an estimate of the numbers of $A B$ observations to be expected per year based on the works of Fritz (1881) and Vestine (1944). Note that we are talking about the numbers expected to be observed, not the numbers actually occurring, as some are always lost due to clouds. Fritz's pioneering work was based on all observations recorded between 1700-1872. Vestine expanded the data base of Fritz by including observations until 1942. As seen in Table 1, the expected sightings of $A B$ ranges from around 20 per year in southern Scandinavia to less than one per year in the Mediterranean. These frequencies represent average conditions and must be applied with care when dealing with short periods. The number of auroras per year follows roughly the eleven-year sunspot cycle. This correlation is weak in the Scandinavian north, but very pronounced in southern Europe where hardly any aurora should be expected around sunspot minimum. A sunspot maximum occurred in 1778 , which means the activity was in decline when the Mannheim network became 
operational. A minimum solar activity was reached around 1784 and thereafter the activity increased until 1789. The life of the network thus spans one solar cycle. Surprisingly it is hard to trace any solar cycle variations in Table 1. Presumably, these are masked by the lack of consistency and uniformity in observational practices. For the majority of the stations the observed frequencies reasonably match the expected values. The exceptions are above all Brussels, Zagan, Mannheim and Padua. Here the observed numbers are definitely too high. The results from Rome and Marseille should also be looked upon with some suspicion, but there the numbers are so small that comparisons are necessarily uncertain. The doubt about Mannheim is confirmed by a comparison with Würzburg. The two are only 100 kilometres apart and consequently we can assume they had similar observing conditions. The same argument can be applied to Padua versus Bologna. Based on statistics alone we can conclude that the observers in Brussels, Zagan, Mannheim and Padua classified more phenomena as $A B$ than most of the others. In other words, the Mannheim network lacked common criteria for what an $A B$ looked like. This is consistent with the fact that the network seems not to have received instruction on this point. Aurora borealis was dealt with in the same way as snow, fog, lightning etc.: you know it when you see it. This procedure works when you are dealing with everyday phenomena, but may fail when they are rare and not well-understood or even welldocumented.

The eleven years that the Mannheim network operated constitute 4000 days. $A B$ is recorded on almost 1000 days, or $25 \%$ of them. The number is unreasonably high, confirming our conclusion above that a large part of the observations does not concern aurora borealis in the modern sense. A closer examination reveals that a considerable proportion of the observations-roughly $20 \%$-are single, meaning that they are not corroborated by simultaneous observations at any other site. The aurora is a large structure easily covering all of Europe when expanding to the south, and given its altitude of 100 kilometres or more, it will be visible at a distance of at least several hundred kilometres. Therefore, an aurora observed from Italy also ought to be seen from the stations further north in Europe. Looking at the 40 events in Padua we find that only 10 of them can be traced to the 
Per Pippin Aspaas \& Truls Lynne Hansen, “The Role of the Societas Meteorologica Palatina (1781-1792)..." final MS version

north. These few very likely constitute the majority of major auroras occurring during the observation period of the Societas Meteorologica. This will bring the number of ABs observed down to a reasonable level. A similar procedure can be applied to observation north of the Alps. On the basis of statistics alone we estimate that the number of "valid" observations should be lowered to less than half of the number of $A B s$ recorded.

\section{If not northern lights, what then ...?}

The statistical breakdown of the data thus demonstrates that somewhere around $50 \%$ of the records of $A B$ in the Ephemerides Meteorologicae are inconsistent with the modern concept of the phenomenon. Still, the observers must surely have seen something. The question remains what they saw and why they classified it as "AB". In order to assess this problem, we have found two sources helpful. First, the editorial prefaces to each volume contain many comments on the aurora and conjectures regarding its cause. Second, many - although not all - stations elaborated on notable observations in a section called "Annotationes speciales". Since the AB was highly liable to be considered as something "special", many individual observations are thus described in more detail in the annotations than in the necessarily laconic tables.

Before discussing individual observations and their interpretations, a brief survey of auroral theories anno 1780 is necessary. Perhaps the most influential of all eighteenth-century books on the aurora was that of Jean-Jacques d'Ortous de Mairan, a member of the Académie Royale des Sciences in Paris. De Mairan's explanation was original in that he assumed a close connection between the aurora and the zodiacal light, a phenomenon more usually seen from southern latitudes (Mairan, 1733). More frequent were explanations pointing to reflections of moisture or ice crystals floating around in the northern part of the sky. This idea was challenged by the fact that the aurora tends to take place several hours after sunset, a circumstance which called for intricate reasoning. One way of saving the hypothesis was to argue that the atmosphere was thicker in the north, thereby refracting the sunlight and making the sunsets last much longer than in the south (e.g. Spidberg, 1724; cf. Lynne 
Per Pippin Aspaas \& Truls Lynne Hansen, “The Role of the Societas Meteorologica Palatina (1781-1792)..." final MS version

Hansen, 2011). Another way of bolstering the hypothesis was to state that the sun and/or the moon was involved (e.g. Hell, 1776, cf. Aspaas \& Lynne Hansen, 2007). Another challenge came from studies of magnetism. The discovery of the 1740 s, that magnetic needles might be affected at the same time as auroral outbreaks (Widmalm, 2012), inspired speculation that the aurora may consist of a magnetic substance arising from some unknown source (some years earlier Halley spoke of "magnetical effluvia" from Earth itself; Halley, 1716). A third hypothesis linked the aurora to electricity. Analogies were drawn with thunder storms, which of course do involve electricity. Contrary to the electricity at play in regular thunderstorms, however, the electricity of the aurora proved problematic if not impossible to measure. Nonetheless, the electricity theory appears to have had many proponents at the time when the Meteorological Society started its activities (e.g. Wilcke, 1778).

A number of atmospheric phenomena could easily have been reported to be aurora, although they clearly were not, at least as understood today. In part lack of experience in regular observation of aurora could result in misinterpreting other lights in the sky, but also for many observers the features and habits of the northern lights were simply still a puzzle for science. For example the Jesuit astronomer Maximilian Hell (1720-1792), during his journey in northern Norway in 1768-69, put crepuscular rays in the same category as the aurora borealis in spite of the fact that they are seen in broad daylight (Aspaas \& Lynne Hansen, 2007). To an eighteenth-century observer the aurora borealis did not necessarily belong to the night. It was not even obvious that the aurora was something taking place above the clouds (cf. Briggs, 1967). Crepuscular rays look like beams of light that seem to come from a common point in the sky, especially when the sun is hidden behind a dense cloud or being below the horizon. The rays are formed by partial obstructions of the light; they are parallel, but appear diverging because of perspective. When investigating the Mannheim records we have looked for cases similar to those recorded by Maximilian Hell, but no certain examples of crepuscular rays were found. 
Another source of possible error, even for modern observers, are moonlit clouds. A full moon hidden behind clouds in an almost overcast sky can illuminate clouds so that they resemble northern lights. In fact, more than $10 \%$ of the $A B s$ in the Mannheim lists are recorded along with overcast or almost overcast skies. We have not been able to point out single events where moonlit clouds are definitely at play. However, it is telling that Father Hell attempted to explain the aurora by means of minute particles of ice in the atmosphere being lit up by the sun or moon from below the horizon. The analogies are clear; both phenomena are seen at night, and they do resemble each other. It is well possible that a number of the observers on the Continent interpreted moonlit clouds as just another form of $A B$.

Yet a second possible source of error is distant clouds lit by the sun from below the horizon that can resemble the reddish northern lights so characteristic of the Continent. This seems to be the case for an observation made on 4 May 1783, when in the Meteora section for Mannheim an "AB init." is recorded (probably, "Aurorae borealis initium", i.e. "the beginning of an Aurora Borealis"; Eph.Met. Anni 1783 [published 1785]: 8). The sky is noted to be completely serene at the time. Mannheim, however, is the only place in the entire network to report an AB that day. In the more elaborate "Annotationes speciales" section, the Mannheim observer (probably Hemmer) notes that, "a great brightness lay fixed on the horizon in the Northwest after sunset" on 4 May $1783 .{ }^{1}$ This may well be an observation of distant clouds lit up by the sun. The circumstance that no other station recorded an $A B$ that evening strongly suggests that it must have been something other than a northern light.

A third possibility is that lightning, in particular distant thunderstorms, can be taken as AB.

The widespread contemporaneous notion of the aurora borealis as an electric phenomenon seems to have underpinned such classification. The editors in Mannheim were themselves a source of inspiration here. The prefaces of the Ephemerides Meteorologicae repeatedly point to this explanation (see below). 
Per Pippin Aspaas \& Truls Lynne Hansen, “The Role of the Societas Meteorologica Palatina (1781-1792)..." final MS version

A fourth possible explanation, noctilucent clouds (NLC) merits some consideration (Fig. 4).

NLC are thin clouds high up in the atmosphere - in the mesosphere around $85 \mathrm{~km}$ altitude - and are therefore sunlit long before sunrise or after sunset. Observers situated in mid and southern Europe not familiar with auroral displays may well have taken NLCs to be auroras. The wavelike structure and electric bluish hue of NLC in fact resemble certain types of aurora. The first observations of NLC were reported in 1885 . This was only two years after the enormous vulcanic eruption of Krakatao; the idea has been put forward that NLC were caused by large amounts of particles injected into the upper-atmospheric mesosphere by the eruption. While this theory may well be correct, it does not explain why NLC were not observed before 1885. After all, volcanic eruptions the size of Krakatao have taken place many times in history. We suggest that NLC have always been there, but were not given a separate designation until the year 1885 . Earlier observers probably put them in the category AB.

In the table the years $1786-87-88$ are remarkable for reporting the sighting of very numerous $A B$. They contribute substantially to the high average frequency of $A B$ in the material. Not only the four stations mentioned, but also several others report far too many $A B$, in particular for the year 1787. Something unusual took place over western Europe these years. A clue is found in the Brussels records. They report numerous events of "AB immobilis" or "AB fixa", that is "not moving". In May 1786 alone there are thirteen days of such cases. Most of these observations are definitely not $A B$.

Most likely the explanation is found in an enormous volcanic eruption on Iceland, known as the Laki eruption. It started in June 1783 and continued until February 1784 and was probably the most powerful eruption on Earth in historic times with respect to lava outflow and gas and dust ejected into the atmosphere (Thordarson \& Self, 2003). Weather in Europe and North America was strongly affected the next several years. In particular, the summer of 1783 and the following winter were extreme with low temperatures and persistent haze (e.g. Kington, 1988; Demarée, 2006). Little is known about the effect of the eruption on the mesosphere, but like the Krakatao case large 
Per Pippin Aspaas \& Truls Lynne Hansen, “The Role of the Societas Meteorologica Palatina (1781-1792)..." final MS version

amounts of dust must have been transported to such heights. We suggest the unusual ABs observed in large numbers from 1786 to 1788 are an effect of the Laki eruption, be it NLC or some other kind of clouds so high up that they were illuminated by the sun long after sunset. ${ }^{2}$

\section{Real and remarkable observations}

It is important to note that, for all the abundance of observations not consistent with today's definition of the aurora, there is no shortage of observations that can be corroborated either by statistical methods or by the descriptions found in the special annotations. One example is this one, from Padua, 13 May 1787 (Eph.Met. Anni 1787 [1789]: 141):

"At 8:45 an aurora borealis was lifted all the way to Zenith, spreading out from the northwest to the northeast. It did not last long. Meanwhile, the magnetic needle showed [a declination of] about 15 degrees 12 minutes; earlier, it had showed 15 degrees 20 minutes." $^{\prime 3}$

This observation is corroborated by simultaneous observations made from ten other sites (Rome, Prague, Marseille, Bologna, La Rochelle, Mannheim, Zagan, Erfurt, Göttingen, Berlin). The simultaneous disturbances of the magnetic needle are also plausible. Moreover, several of the other sites have annotations on this particular auroral outbreak that underscore this point.

Certain descriptions are harder to interpret. A noteworthy annotation of an AB was made in Zagan on 1 April 1788 (Eph.Met. Anni 1788 [1790]: 286):

“9 o'clock in the evening, a red and orange AB without rays. Now other, darker clouds rise like a column of clouds in the north, red and yellow to the right, to the left yellow only. Still 10 o'clock the light beams through the clouds. At 10:15 hammering rain." ${ }^{4}$

Basically, this description makes sense. It is too late for the sunset to be involved, and the movement and colours appear to exclude moonlit clouds. On the other hand, there were no observations from other stations that day, but several on the days following it. It is interesting to note, however, that 
Per Pippin Aspaas \& Truls Lynne Hansen, “The Role of the Societas Meteorologica Palatina (1781-1792)..." final MS version

cloudy weather appears to have been a natural companion of the aurora to the observers in Zagan; so natural, in fact, that they did not hesitate to describe the aurora itself as a cloud.

Philosophers and historians of science have long noted the tendency of even the most trained scientists to make "theory-laden observations". The "theory ladenness" of the Mannheim Society is easily distinguishable in the special annotations, such as the striving to find $A B s$ accompanying thunderstorms as a corollary of the presumed electrical nature of the aurora. In fact, two incidental occurrences seem to have excited members of the Meteorological Society. A strong auroral outbreak over Europe on 13 October 1786 was accompanied by a thunderstorm in Padua (but no other place in the network). Another outbreak on 13 July 1787 took place in conjunction with a thunderstorm in Mannheim (again exclusively). That these were auroras corresponding to the modern sense of the term, is corroborated by simultaneous observations at five and nine other stations respectively (Eph.Met. Anni 1786 [1788]; Eph.Met. Anni 1787 [1789]). In the preface to the volume for the year 1786 the editors remarked:

"The observation that our esteemed colleagues in Padua have made, namely that an aurora borealis has flashed forth in the sky at the same time as lightning, is truly remarkable. That each of the two lights [i.e., aurora and lightning - the authors] has burst forth from the same cloud in continuous succession is something that we have noted thrice here in Mannheim, as we will explain in the next volume. This phenomenon lends no small measure of support to the opinion of those who claim that the auroras are an electric effect.".5

What we now understand to have been a matter of pure coincidence seems to have prompted several observations of " $A B$ " appearing at the same time as lightning in tthe following years. One of these - 13 November 1787 - was made in Mannheim only, and that during completely overcast weather (Eph.Met. Anni 1787 [1789]: 12 \& 29). The theory of electric northern lights seemingly influenced the observers to expect to see aurora together with thunderstorms. They were then predisposed to perceive visual effects in the sky accordingly. 
Per Pippin Aspaas \& Truls Lynne Hansen, “The Role of the Societas Meteorologica Palatina (1781-1792)..." final MS version

There is another likely reason for the high number of $A B s$ reported: in an empirically-based field of inquiry such as early modern meteorology, "to witness gives authority". In order to gain authority as auroral researchers, the organizers in Mannheim needed to gather as many eye-witness accounts as possible, as that was likely to lend more weight to their theoretical deliberations.

Similarly a sense of prestige certainly also accompanied an observer who reported frequent sightings of such an enigmatic phenomenon.

\section{Concluding remarks}

The Meteorological Society of Mannheim was set up to coordinate observations of the weather on an international scale. It also developed into a network for auroral research as well. However, while it succeeded quite well in gathering consistent sets of data for temperature, pressure and humidity, its recordings of "meteora" were less successful when analysed with the benefit of hindsight. In our analysis, we have gone through 1323 alleged observations of "AB", or northern lights, made at twenty-nine sites in western Europe and recorded in the Ephemerides Meterologicae Societatis Palatinae. Our investigation demonstrates that in the 1780 s the aurora was a phenomenon that as yet defied concensual agreement as to its visual features as well as its nature. Descriptions of the aurora in tune with modern concepts seem to have been widespread in Scandinavia, but not yet established on the Continent, where the colour and infrequency of the aurora rendered it more likely to be confused with other phenomena. To observers in the North the aurora was common, greenish and easy to recognise (Fig. 2). To observers far south of the auroral zone it was rare, generally red or pale and hard to distinguish from other phenomena in the sky (Fig. 3).

This situation has consequences for historians of science as well as for climate change researchers. Surveys of the history of research into the northern lights tend to underestimate the fact that a variety of understandings of the aurora that cannot be reconciled with the modern concept of the phenomenon co-existed for a very long time in Europe. Climate-change researchers 
tend to take the reliability of past records for granted and use them for their models of solar activity without subjecting them to relevant critical scrutiny.

Having said that, not every observation is permeated by notions that are incompatible with the modern concept of the phenomenon. Certain strong auroral outbreaks were unquestionably visible even in southern Europe during the years of the Meteorological Society's activities. These are not immediately recognizable, and need to be sought out from the non-standardized and inconsistent data by means of critical analysis and statistical methods.

The Societas Meteorologica Palatina of Mannheim sought to solve the riddle of the northern lights. It did not, however, turn to the High North in this endeavour. Further research is needed to clarify why. However, it seems safe to conclude that to the coordinators in Mannheim, the aurora constituted an enigma that was just as likely to be solved on the Continent by means of observations assembled in the south, as anywhere else in the world. The status of the aurora as a phenomenon "belonging" to the Far North is thus rendered less obvious when faced with the role played by the Meteorological Society of Mannheim in the period from 1781 to 1792.

TABLE 1 Number of AB observations per station each year

\begin{tabular}{|c|c|c|c|c|c|c|c|c|c|c|c|c|c|c|}
\hline Site & $\begin{array}{l}\text { Magn. } \\
\text { latitude }\end{array}$ & $\begin{array}{l}17 \\
81\end{array}$ & $\begin{array}{l}17 \\
82\end{array}$ & $\begin{array}{l}17 \\
83\end{array}$ & $\begin{array}{l}17 \\
84\end{array}$ & $\begin{array}{l}17 \\
85\end{array}$ & $\begin{array}{l}17 \\
86\end{array}$ & $\begin{array}{l}17 \\
87\end{array}$ & $\begin{array}{l}17 \\
88\end{array}$ & $\begin{array}{l}17 \\
89\end{array}$ & $\begin{array}{l}17 \\
90\end{array}$ & $\begin{array}{l}17 \\
91\end{array}$ & $\begin{array}{l}\text { Per } \\
\text { year }\end{array}$ & $\begin{array}{l}\text { Expect } \\
\text { ed }\end{array}$ \\
\hline $\begin{array}{l}\text { Spydeberg/ } \\
\text { Eidsberg }\end{array}$ & 62.1 & - & - & 16 & 16 & 12 & 24 & 26 & 27 & - & - & - & 20.1 & 25 \\
\hline Stockholm & 60.6 & - & - & 24 & 8 & 10 & 25 & 55 & - & - & - & - & 24.4 & 20 \\
\hline Copenhagen & 58.2 & - & 12 & 12 & 4 & 2 & 9 & 10 & 2 & - & - & - & 7.3 & 10 \\
\hline The Hague/Delft & 56.2 & - & $\begin{array}{l}4 \\
*\end{array}$ & $\begin{array}{l}1 \\
*\end{array}$ & $\begin{array}{l}3 \\
*\end{array}$ & - & 10 & - & - & - & - & - & 4.5 & 7 \\
\hline
\end{tabular}




\begin{tabular}{|c|c|c|c|c|c|c|c|c|c|c|c|c|c|c|}
\hline Middelburg & 55.7 & - & 1 & 8 & 1 & 2 & 2 & 1 & - & - & - & - & 2.5 & 6 \\
\hline Berlin & 55.0 & 5 & 8 & 9 & 6 & 6 & 25 & 9 & 2 & - & - & - & 8.8 & 5 \\
\hline Brussels & 55.0 & - & 2 & 0 & 0 & 8 & 33 & - & 19 & 25 & 9 & 13 & 12.1 & 5 \\
\hline Düsseldorf & 54.9 & - & - & 2 & 1 & 0 & - & 12 & - & - & - & - & 3.5 & 5 \\
\hline Göttingen & 54.7 & - & - & 2 & 0 & 0 & 0 & - & 12 & - & - & - & 2.8 & 5 \\
\hline Erfurt & 54.0 & 13 & 2 & 9 & 2 & 2 & 2 & 14 & 8 & - & - & - & 6.5 & 4 \\
\hline Zagan & 53.8 & 11 & 10 & 14 & 6 & 7 & 28 & 33 & 41 & 30 & 25 & 14 & 19.9 & 4 \\
\hline Würzburg & 53.0 & 4 & 0 & 0 & 1 & 0 & 1 & 8 & 3 & - & - & - & 2.1 & 3 \\
\hline Mannheim & 53.0 & 11 & 16 & 9 & 7 & 8 & 21 & 37 & 26 & 9 & 13 & 8 & 15.0 & 3 \\
\hline Prague & 52.5 & 4 & 6 & 12 & 4 & 0 & 8 & 14 & - & 2 & 4 & 1 & 5.5 & 3 \\
\hline Regensburg & 51.9 & 8 & 3 & 7 & 3 & 0 & 4 & 14 & 8 & 8 & 1 & 1 & 5.2 & 3 \\
\hline Dijon & 51.5 & - & - & 2 & 2 & - & - & - & - & - & - & 0 & 1.3 & 3 \\
\hline Munich & 51.2 & 2 & 0 & 0 & 0 & 0 & 1 & 9 & 3 & 0 & 0 & 1 & 1.5 & 2 \\
\hline La Rochelle & 51.1 & - & 3 & 4 & 5 & 2 & 1 & 22 & 3 & 2 & - & - & 5.3 & 3 \\
\hline Andechs & 51.1 & 1 & 0 & 1 & 0 & 0 & 1 & 4 & 0 & 2 & - & - & 1.0 & 2 \\
\hline $\begin{array}{l}\text { Hohenpeissen- } \\
\text { berg }\end{array}$ & 51.0 & 3 & 1 & 1 & 2 & 1 & 1 & 7 & 1 & 5 & 3 & 0 & 2.3 & 2 \\
\hline Tegernsee & 50.7 & 0 & 5 & 1 & 0 & 3 & 4 & 4 & 3 & 0 & - & - & 2.2 & 1.5 \\
\hline Geneva & 50.2 & - & - & - & 1 & 0 & 0 & 1 & 4 & 2 & - & - & 1.3 & 1.5 \\
\hline St. Gotthart & 50.2 & 0 & 0 & 0 & 0 & 0 & 0 & 1 & 1 & 0 & 0 & 1 & 0.3 & 1.5 \\
\hline Budapest & 49.2 & 0 & 1 & 1 & 0 & 0 & 1 & 7 & 4 & 1 & 0 & 0 & 1.4 & 1 \\
\hline Padua & 48.5 & 4 & 4 & 5 & 4 & 5 & 6 & 10 & 5 & 0 & 0 & 2 & 4.1 & 0.8 \\
\hline Bologna & 47.7 & - & 1 & 0 & 0 & 0 & - & 8 & 0 & 0 & 0 & 0 & 0.8 & 0.5 \\
\hline Marseille & 47.5 & - & - & - & - & - & 3 & 3 & 2 & 2 & - & 0 & 2.0 & 0.5 \\
\hline Rome & 44.9 & - & 0 & 0 & 0 & 0 & 3 & 7 & 6 & 2 & 0 & 0 & 1.8 & 0.3 \\
\hline
\end{tabular}

- means station not reporting.

* by the number means the observations are found in annual summary tables only. Thus date in year is unknown.

Magn. Latitude is geomagnetic latitude in degrees. We have used dipole latitude estimates for 1785 calculated with dipole pole coordinates 79.5 degrees North, 304 degrees East (Langel 1987, p. 388).

The column Per year gives the average number of ABs per year the station reported.

Expected is the number of observations per year based on the work of Vestine (1944).

The stations most significantly deviating from the expected frequency have been marked in yellow. 


\section{FIGURE 1}

Geographical distribution of the 29 stations of the Societas Meteorologica Palatina whose observations of auroras are analysed in Table 1. The red lines give an approximation of the auroral zone, where the aurora borealis occurs most frequently. Graphics by Magnar Gullikstad Johnsen in collaboration with the authors.

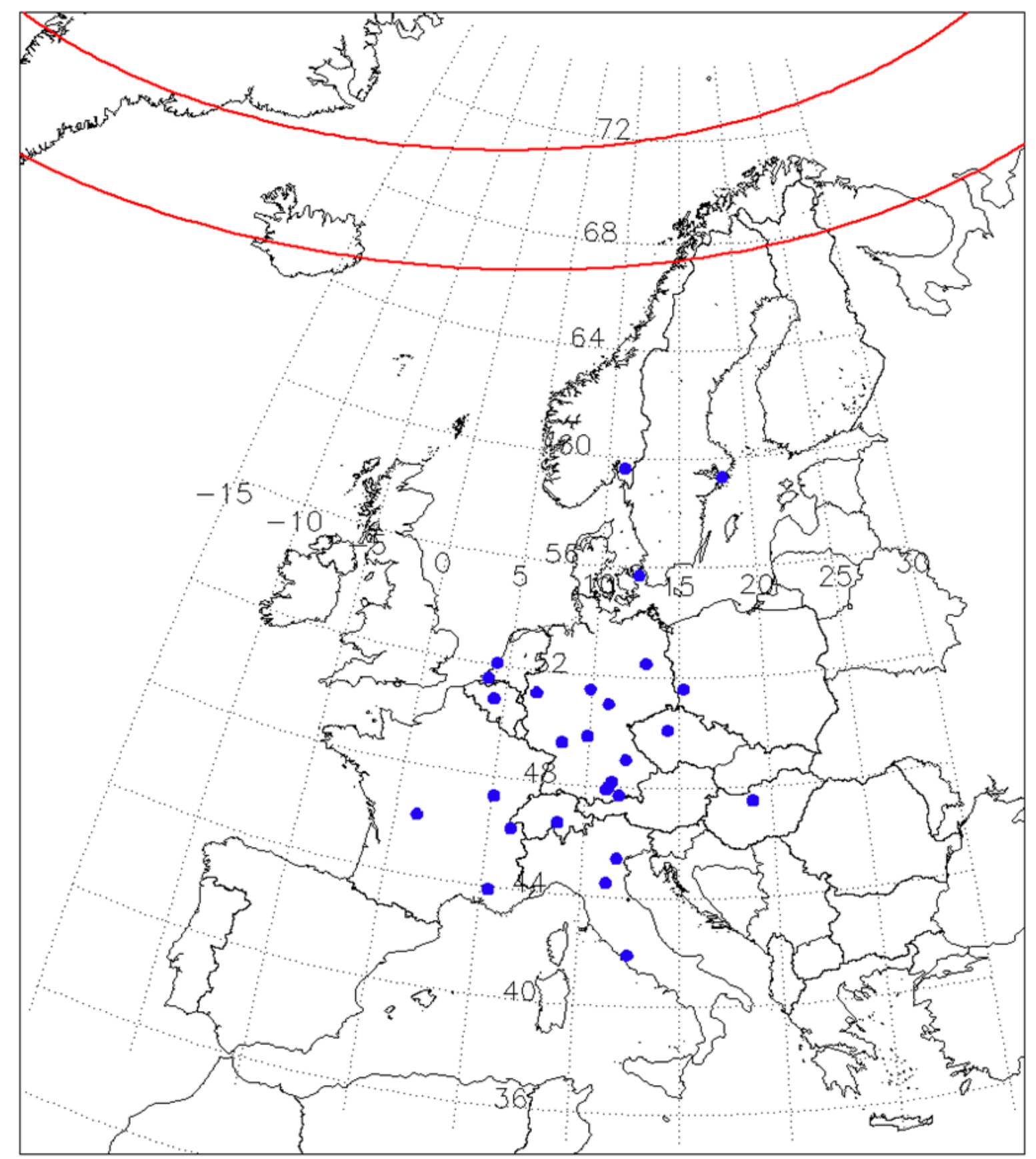




\section{FIGURE 2}

Northern Lights over Kvaløya, Norway, April 2008. Photograph by M. Buschmann. Wikimedia Commons.

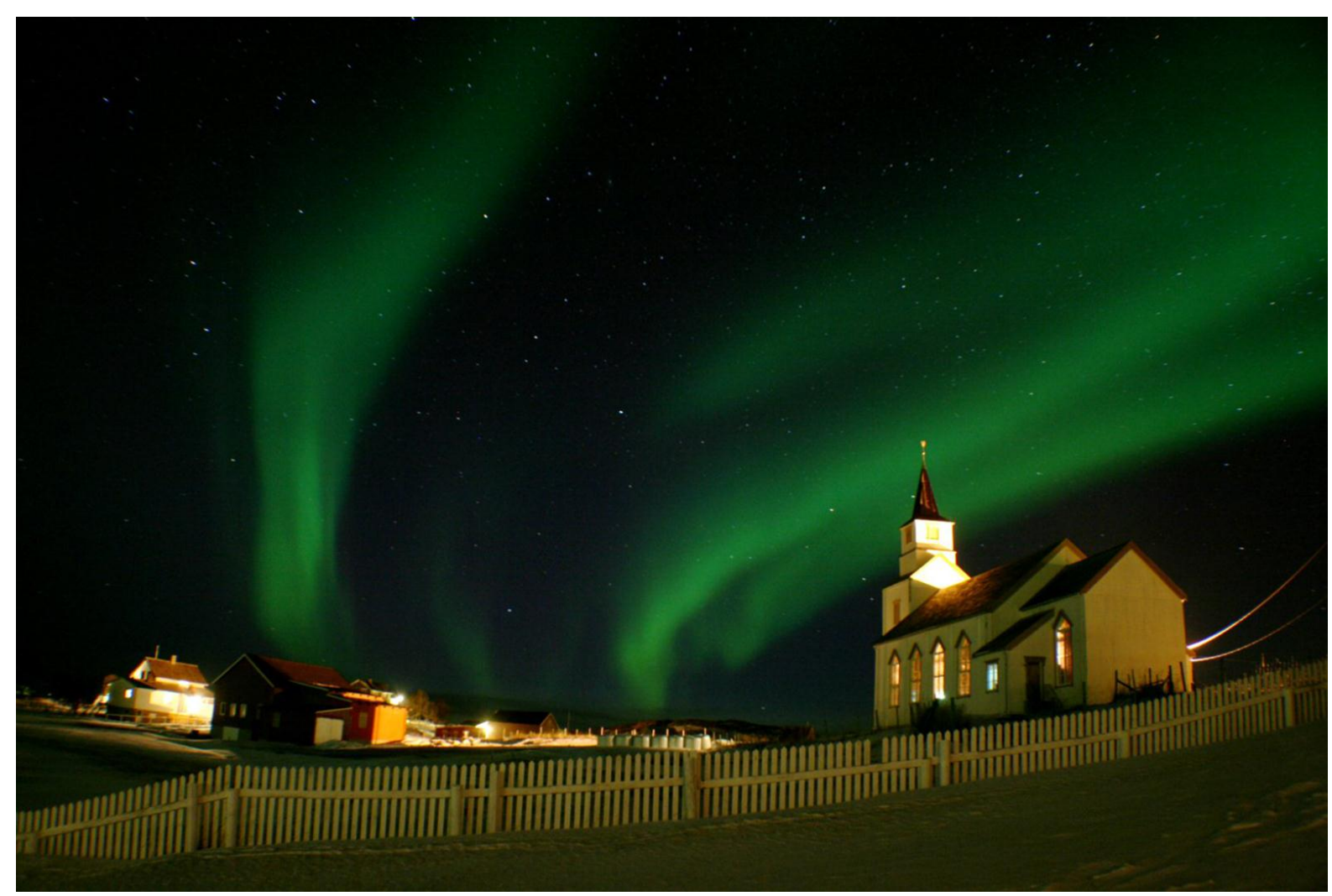




\section{FIGURE 3}

Aurora borealis in Cortina d'Ampezzo, Italy, October 2003. Photograph by Giuseppe Menardi, http://www.cortinastelle.it/aurora30102003.htm. Reproduced with permission.

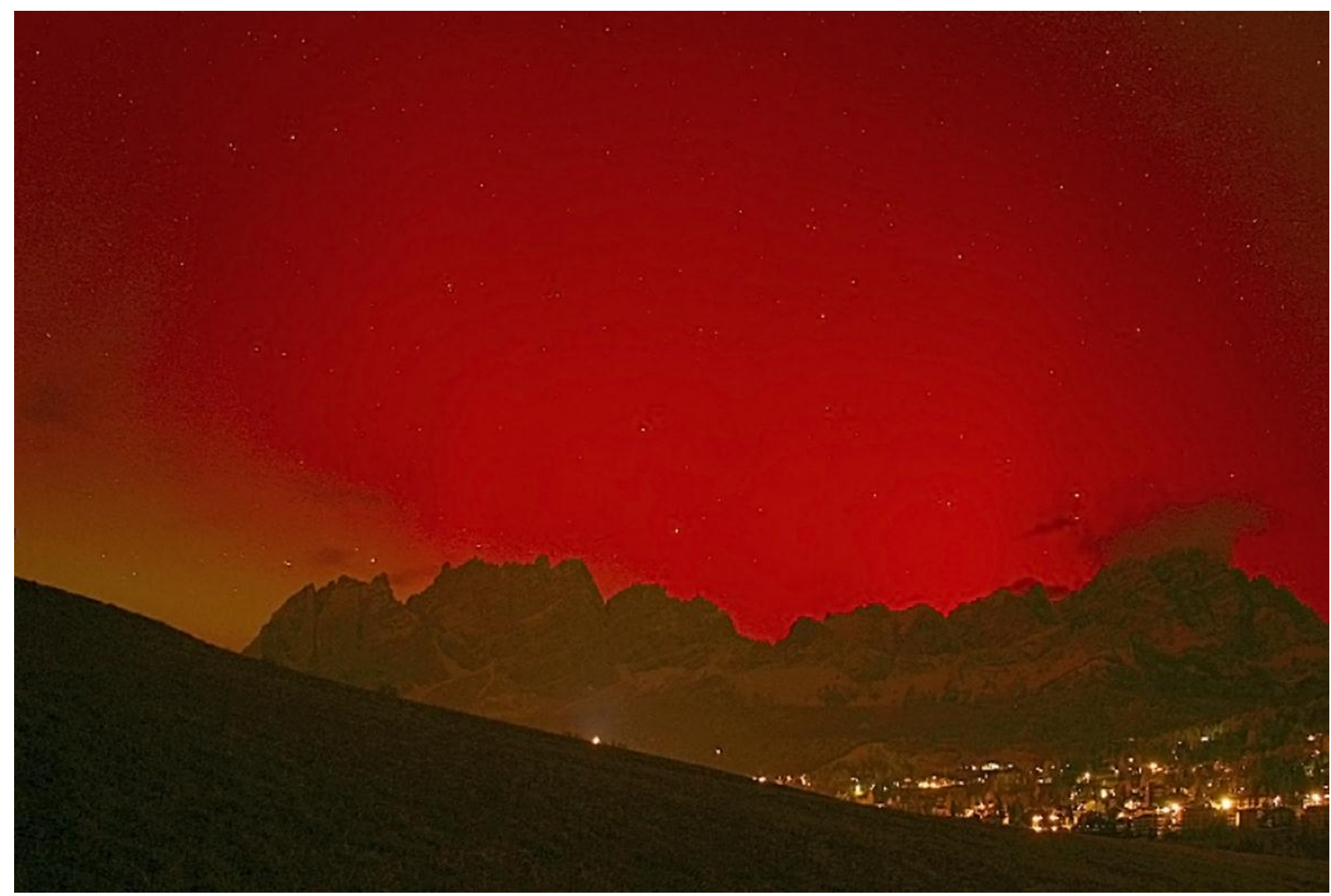




\section{FIGURE 4}

Noctilucent clouds over Lake Saimaa, Finland, August 2003. Photograph by Mika Yrjölä. Wikimedia commons.

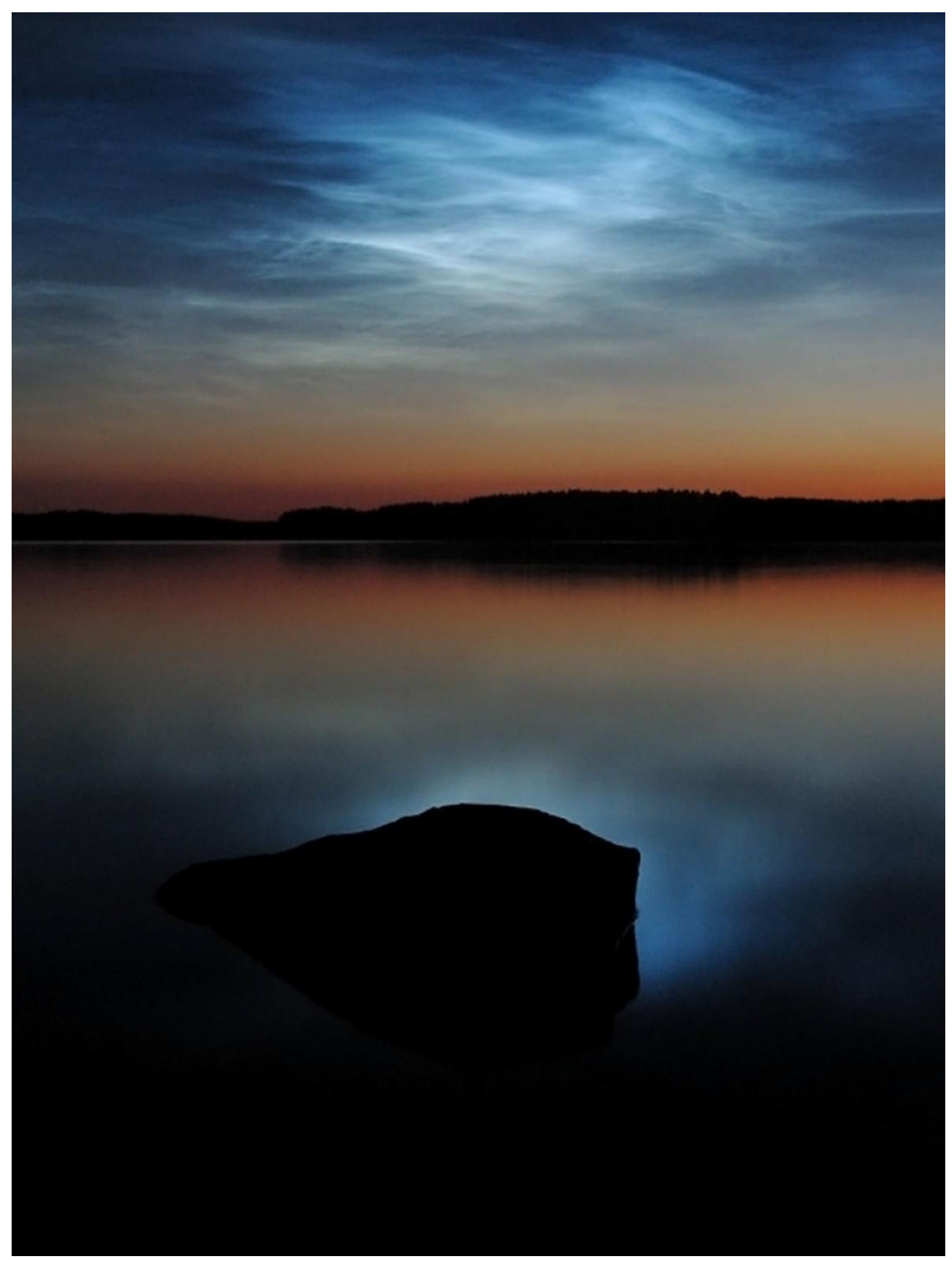




\section{References}

Andersen, H. With, Brenna, B., Njåstad, M. \& Wale, A. (2009). Aemula Lauri: The Royal Norwegian Society of Sciences and Letters, 1760-2010 (Sagamore Beach, Mass.: Science History Publications). Anon. (Ed.), (1980). Symposium anläßlich der 200. Wiederkehr des Gründungsjahres der Societas Meteorologica Palatina, Mannheim, 13.-15. Oktober 1980 (Offenbach am Main: Selbstverlag des Deutschen Wetterdienstes).

Aspaas, P.P. (2012). Maximilianus Hell (1720-1792) and the Eighteenth-Century Transits of Venus: A Study of Jesuit Science in Nordic and Central European Contexts, PhD dissertation, Department of History and Religious Studies, University of Troms $\varnothing$. http://munin.uit.no/handle/10037/4178

Aspaas, P.P. (2013). The Auroral Zone versus the Zone of Learning: A Brief History of Early Modern Theories of the Aurora Borealis, in S. Gaupseth, M.-T. Federhofer \& P.P. Aspaas (Eds.), Travels in the North, forthcoming (Hannover: Wehrhahn).

Aspaas, P.P. \& Lynne Hansen, T. (2007). Geomagnetism by the North Pole, anno 1769: The Magnetic Observations of Maximilian Hell during his Venus Transit Expedition, Centaurus 49, pp. 138-164.

Brekke, A. \& Egeland, A. (1994). The Northern Lights: Their Heritage and Science, translated by James Anderson (first Norwegian edn. 1979) (Oslo: Grøndahl Dreyer).

Briggs, J.M. (1967). Aurora and Enlightenment: Eighteenth-Century Explanations of the Aurora Borealis, Isis 58, pp. 491-503.

Cassidy, D.C. (1985). Meteorology in Mannheim: The Palatine Meteorological Society, 1780-1795, Sudhoffs Archiv 69, pp. 8-25.

Colacino, M. \& Valensise, M.R. (1994). The Role of the Cimento Academy and the Meteorologica Societas Palatina in the birth of the modern meteorology, in Schröder \& Colacino (Eds.), Geophysics: 
Per Pippin Aspaas \& Truls Lynne Hansen, “The Role of the Societas Meteorologica Palatina (1781-1792)..." final MS version

Past achievements and future challenges, pp. 9-29 (Bremen: Interdivisional commission on history of the International Association of Geomagnetism and Aeronomy).

Dalin, P., Pertsev, N., \& Romejko, V. (2012). Notes on historical aspects on the earliest known observations of noctilucent clouds, History of Geo- and Space Sciences 3, pp. 87-97.

Demarée, G.R. (2006). The catastrophic floods of February 1784 in and around Belgium - a Little Ice Age event of frost, snow, river ice ... and floods, Hydrological Sciences Journal / Journal des Sciences Hydrologiques 51, pp. 878-898.

Der Drontheimischen Gesellschaft Schriften aus dem Dänischen übersetzt, Erster - Dritter Theil (1765-1767).

Der Königl. Norwegischen Gesellschaft der Wissenschaften Schriften aus dem Dänischen übersetzt, Vierter Theil (1770).

Eather, R.H. (1980). Majestic lights: The Aurora in Science, History, and the Arts (Washington, D.C.: American Geophysical Union).

Enebakk, V. (2012). Appropriating the Aurora: Christopher Hansteen and the Circumpolar Auroral Rings. This issue.

Eph. Met. $=$ Ephemerides Meteorologicae Societatis Palatinae Anni 1781 (published 1783) - Anni 1792 (published 1795).

Federhofer, M.-T. (2001). Wetterzeichen. Zum meteorologischen Kodierungsverfahren Jacob Nicolaj Wilses (1735-1801), Cardanus. Jahrbuch für Wissenschaftsgeschichte 2, pp. 13-29.

Feldman, T.S. (1990). Late Enlightenment Meteorology, in T. Frängsmyr, J.L. Heilbron \& R.E. Rider (Eds.) The Quantifying Spirit in the $18^{\text {th }}$ Century, pp. 143-179 (Berkeley: University of California Press). 
Per Pippin Aspaas \& Truls Lynne Hansen, “The Role of the Societas Meteorologica Palatina (1781-1792)..." final MS version

Frängsmyr, C. (2000). Klimat och karaktär. Naturen och människan i sent svenskt 1700-tal

(Stockholm: Natur och kultur).

Fritz, H. (1873). Verzeichniss beobachteter Polarlichter (Wien: C. Gerold's Sohn).

Fritz, H. (1881). Das Polarlicht (Leipzig: F.A. Brockhaus).

Halley, E. (1716). An Account of the Late Surprizing Appearance of the Lights Seen in the Air, on the Sixth of March Last; With an Attempt to Explain the Principal Phaenomena thereof, Philosophical Transactions of the Royal Society of London 29, pp. 406-428.

Kington, J. (1988). The Weather of the 1780s over Europe (Cambridge: Cambridge University Press).

Kistner, A. (1930). Die Pflege der Naturwissenschaften in Mannheim zur Zeit Karl Theodors, Geschichte der Kurpfälzischen Akademie der Naturwissenschaften vol. 1 (Mannheim: Selbstverlag des Mannheimer Altertumsvereins).

Langel, R.A (1987). The Main field, in J.A. Jacobs (Ed.) Geomagnetism vol. 1, pp. 249-512 (London: Academic Press).

Lindroth, S. (1978). Svensk lärdomshistoria vol. 2: Frihetstiden (Stockholm: P. A. Norstedt).

Lindroth, S. \& Eriksson, G. (1981). Svensk lärdomshistoria vol. 3: Gustavianska tiden (Stockholm: P. A. Norstedt).

Lüdecke, C. (2002). Meteorologische Messungen im 18. Jahrhundert, in E. Donnert (Ed.) Europa in der Frühen Neuzeit vol. 6: Mittel-, Nord und Osteuropa: Festschrift für Günter Mühlpfordt, pp. 951-953 (Köln: Böhlau).

Lüdecke, C. (2005). East meets west: Meteorological observations of the Moravians in Greenland and Labrador in the 18th century, History of Meteorology 2, pp. 123-132. 
Per Pippin Aspaas \& Truls Lynne Hansen, “The Role of the Societas Meteorologica Palatina (1781-1792)..." final MS version

Lüdecke, C. (Ed.), (2006). Deutsche Meteorologische Gesellschaft (DMG), Fachausshuß Geschichte der Meteorologie (FAGEM), Tagung 2006: "Das Wetter Festhalten": 225. Jubiläum des Meßnetzes der Societas Meteorologica Palatina 1781-1792: Zusammenfassung der Vorträge (Mannheim: Landesmuseum für Technik und Arbeit).

Lynne Hansen, T. (2011). En prest om nordlyset - Jens Spidbergs skrift fra 1724, in M.-T. Federhofer \& H. Hodacs (Eds.) Mellom pasjon og profesjonalisme: Dilettantkulturer i skandinavisk kunst og vitenskap, pp. 93-102 (Trondheim: Tapir Akademisk Forlag).

Mairan, [J.J.] d'Ortous de (1733). Traité Physique et Historique de l'Aurore Boréale (Paris:

L'Imprimerie Royale).

Moutchnik, A. (2006). Forschung und Lehre in der zweiten Hälfte des 18. Jahrhunderts: Der Naturwissenschaftler und Universitätsprofessor Christian Mayer SJ (1719-1783) (Augsburg: Dr. Erwin Rauner Verlag).

Pihlaja, P.M. (2009). Tiedettä pohjantähden alla: Pohjoisen tutkimus ja Ruotsin tiedeseurojen suhteet Ranskaan 1700-luvulla, Bidrag till kännedom av Finlands natur och folk 181 (Helsinki: Suomen tiedeseura).

Pihlaja, P.M. (2012). Science Societies, Laboratories of Nature and the Quest for Scientific Honour in Early Modern Sweden. This issue.

Ruiu, A. (2007). Les récits de voyage aux pays froids au XVIle siècle: De l'expérience du voyageur à l'experimentation scientifique (Montréal: Imaginaire/Nord).

Sandahl, I. (1998). Norrsken: Budbärare från rymden (Stockholm: Atlantis).

Schröder, W. \& Colacino, M. (Eds.), (1994). Geophysics: Past achievements and future challenges (Bremen: Interdivisional commission on history of the International Association of Geomagnetism and Aeronomy). 
Per Pippin Aspaas \& Truls Lynne Hansen, “The Role of the Societas Meteorologica Palatina (1781-1792)..." final MS version

Schröder, W. (2000). The Aurora in Time (reprint of Das Phänomen des Polarlichts:

Geschichtsschreibung, Forschungsergebnisse und Probleme Darmstadt 1984, with an English summary), (Bremen: Science Edition).

Siscoe, G.L. (1978). An Historical Footnote on the Origin of 'Aurora Borealis', EOS: Transactions of the American Geophysical Union 59, pp. 994-997.

Spidberg, J.Chr. (1724). Historische Demonstration und Anmerckung über die Eigenschafften und Ursachen des so genandten Nord-Lichts (Halle: Johann Adam Spörl).

Stauning, P. (2011). Danish auroral science history, History of Geo- and Space Sciences 2, pp. 1-28.

Thordarson, T. \& Self, S. (2003). Atmospheric and environmental effects of the 1783-1784 Laki eruption: a review and reassessment, Journal of Geophysical Research: Atmospheres 108, 4011, pp. $1-29$.

Vestine, E.H. (1944). The geographical incidence of aurora and magnetic disturbance, northern hemisphere, Terrestrial Magnetism and Atmospheric Electricity 49, pp. 77-102.

Widmalm, S. (1992). A Commerce of Letters: Astronomical Communication in the 18th Century, Science Studies 5, pp. 43-58.

Widmalm, S. (2012). Character and Property in 18th-Century Swedish Astronomy: The Case of the Magnetic Aurora. This issue.

Wilcke, J.C. (1788). Tal, om De nyaste Förklaringar öfver Norr-Skenet, hållet, i Kongl. Maj:ts höga nårvaro, för dess Vetenskaps-Academie (Stockholm: Johan Georg Lange). 


\footnotetext{
${ }^{1}$ Eph.Met. Anni 1783 (published 1785): 55: "Candor ingens post solis occasum horizonti in N W insidebat" (translated by the authors).

${ }^{2}$ In a recent publication, Dalin et al. (2012) have argued that the eruption of Laki 1783 is likely to have produced noctilucent clouds. However, they have no reference to the reports of the Mannheim Society and do not discuss the aurora borealis as a likely source of confusion.

3 "Hora $83 / 4$ aurora borealis usque ad Zenith elata, extensa a cauro usque ad Euro-Boream, parum durat. Acus magnetica signat interim $15^{\circ}, 12$ circiter; prius signabat $15^{\circ}, 20^{\prime \prime}$ (translated by the authors).

4 "Vesp. h. $9 A B$ rubens \& flavescens sine radiis, nunc praeter alias obscuriores nubes quasi columna nubis in $\mathrm{N}$, ad dextram rub. \& flav., ad laevam tantum flav. Hora 10 adhuc inter nubes lumen transparet. Hora 101/4 imber." (translated by the authors).

${ }^{5}$ Eph.Met. Anni 1786 (1788): VI: "Egregia plane observatio est, quam Patavii cl. sodales nostri fecerunt, auroram borealem in coelo \& coruscationes eodem tempore emicuisse. Utramque hanc lucem continenti successione ex eadem nube prodiisse, \& nobis Manheimii ter observatum est, uti in proximo volumine dicemus. Ex quo phaenomeno non leve momentum ei opinioni accedit, quae auroras boreales effectum electricum esse contendit" (translated by the authors).
} 